\title{
THE CONTROL OF APRICOT SEED DORMANCY AND GERMINATION BY LOW TEMPERATURE TREATMENTS
}

\author{
SAMIR A SEIF EL-YAZAL ${ }^{1}$, MOHAMED A EI-YAZAL \\ ${ }^{1}$ Department of Horticulture, Faculty of Agriculture, Fayoum University, Fayoum 63514, Egypt. ${ }^{2}$ Department of Botany, Faculty of \\ Agriculture, Fayoum University, Fayoum 63514, Egypt. E-mail: sas00@fayoum.edu.eg
}

Received: 02 January 2021, Revised and Accepted: 09 Febuary 2021

\section{ABSTRACT}

Objective: Freshly harvested seeds of "Local" apricot variety were found to be dormant and did not germinate at all. A specific low-temperature stratification treatment was required to overcome seed dormancy. The most effective temperature for breaking seed dormancy, germination, and seedling growth was $5^{\circ} \mathrm{C}$ cold stratification (CS). Increased seed germination percentage was recorded when the period of stratification prolonged. Seedling developed from stratified seeds had better growth than those developed from non-stratified seeds.

Methods: For stratification treatments, the seeds with removed endocarp were mixed with moistened sand. Afterward, they were subjected to a period of stratification at $5^{\circ} \mathrm{C}$. Seeds were stratified in pots of $30 \mathrm{~cm} \times 40 \mathrm{~cm}$. Stratified seeds were regularly irrigated once per week. To prevent the water loss during stratification upper surface of pots was covered by a sack. The following stratification was applied for apricot variety: CS for $0,3,6$, 9, 12, and15 days in 1998 and 1999 years for "Local" variety.

Results: Apricot seeds required a CS of about 15 days for "Local" variety to reach maximum germination and normal seedling growth. Moreover, when stratification period was prolonged, some of the chemical constituents of apricot seeds were increased and other was decreased. Therefore, it can be suggested that breaking of dormancy is coincided with several changes in different chemical constituents of seeds. Some of these materials increased (total, reducing and non-reducing sugars, total free amino acids, total indoles, and total and conjugated phenols) and other materials such as free phenols which decreased at seed germinations.

Conclusion: The most effective temperature for breaking seed dormancy, germination, and seedling growth was $5^{\circ} \mathrm{C}$ CS. Increased seed germination percentage was recorded when the period of stratification prolonged. Seedling developed from stratified seeds had better growth than those developed from non-stratified seeds.

Keywords: Apricot (Prunus armeniaca L.), Dormancy, Stratification, Germination, Seedling growth, Chemical constituents.

(C) 2021 The Authors. Published by Innovare Academic Sciences Pvt Ltd. This is an open access article under the CC BY license (http://creativecommons, org/licenses/by/4.0/) DOI: http://dx.doi.org/10.22159/ijags.2021v9i1.40689. Journal homepage: https://innovareacademics.in/journals/index.php/ijags

\section{INTRODUCTION}

Prunus is a large, diverse genus in Rosaceae commonly referred to as stone fruits. Principle commercial crops in this genus include peaches, nectarines, plums, prunes, apricots, cherries, and almonds. Seeds of stone fruits do not germinate immediately after harvest and a period of after ripening is essential for certain chemical and other changes to take place in the seed and for dormant embryo to grow [1]. Seed dormancy is a physiological phenomenon in plants, which is caused by external or internal factors, and prevents of seeds germination, even in optimal conditions. Seed dormancy may be caused due to hard seed coat, immature embryo, rudimentary embryo, and inhibitors materials [2]. In this respect, García-Gusano et al. [3] reported two independent dormancies in seeds of stone fruit a physical (external) and embryo (internal) dormancy which are essential for better survival and establishment of seedlings in the field. Seeds of temperate fruit species need a long time to germinate as a result of their requirement of stratification or cold treatment $[1,4]$. Seeds of temperate fruit species do not germinate as a result of seed dormancy even if conditions such as water, temperature, and oxygen are suitable for germination. Seed and bud dormancy is classified as physiological, morphological, morpho-physiological, physical, and combinational dormancy (physical and physiological) [5-11]. These mechanisms of dormancy are present in the seeds of all temperature fruit species, including peach, cherry, and apricot $[12,13]$. In general, these germination problems in temperate fruit species are successfully overcome by cold stratification (CS) of seeds for several months during winter. However, seeds of temperate fruit species require a long time to germinate under traditional stratification or natural conditions. Therefore, fast and uniform germination techniques are desirable for fruit-growing and breeding studies [14]. Various methods have been tried to overcome dormancy of stone fruits. Stratification has been used traditionally to break seed dormancy in Prunus sp. [6] (Finch-Savage and Leubner-Metzger, 2006). Scarification can be done either mechanically or chemically [2]. Several researchers working on breaking dormancy such as Rady and El-Yazal [15], Rady and ElYazal [16] El-Yazal and Rady [17] El-Yazal et al. [18] El-Yazal and Rady [19] El-Yazal and Rady [20] El-Yazal et al. [21] El-Yazal et al. [22] ElYazal et al. [23] El-Yazal et al. [24] El-Yazal et al. El-Yazal [26] on buds and Şan [1], Mark [27], Keun et al. [28], Pliszko and KostrakiewiczGierałt [29], Pliszko and Kostrakiewicz-Gierałt [30] Pliszko and Kostrakiewicz-Gierałt [31] Górnik et al. [32] on seeds. The beneficial effect of stratification on seed germination was studied by Seng and Cheong [33] Yan and Chen [34] Guo et al. [35].

\section{MATERIALS AND METHODS}

The fruits of apricot variety "Local" were collected from bearing trees grown in private orchard at Ibshawai district, Fayoum Governorate, Egypt, by hand-stripping in June 1998 and 1999. All the fruits were packed in plastic bags and transported to the laboratory. Seeds obtained by breaking fruits were sampled randomly for all the experiments. Initial viability was obtained using the cutting method. The seeds were washed carefully with tap water and air dried. Hard shell (endocarp) of seeds was removed. Seeds were stored in opened-mouth jams at room temperature before stratification treatments were applied. 


\section{Stratification treatments}

For stratification treatments, the seeds with removed endocarp were mixed with moistened sand. Afterward, they were subjected to a period of stratification at $5^{\circ} \mathrm{C}$. Seeds were stratified in pots of $30 \mathrm{~cm} \times 40 \mathrm{~cm}$. Stratified seeds were regularly irrigated once per week. To prevent the water loss during stratification upper surface of pots was covered by a sack. The following stratification was applied for apricot variety: CS for 0, 3, 6, 9, 12, and 15 days in 1998 and 1999 years for "Local" variety. Seeds sowing time (ST) in $1^{\text {st }}$ July of 1998 and $15^{\text {th }}$ July 1999 years. Control seeds sowing without Cold stratification. Dishes were placed at $25^{\circ} \mathrm{C}$ in incubators to allow germination. The germination $\%$ was calculated at 3 days interval during a period of 15 days.

\section{Effect of exposed seed to CS on growth characters of seedling after} 120 days from planting

During 1998 and 1999 seasons, samples of three replicates each of 15 seeds were stratified at $5^{\circ} \mathrm{C}$. The first sample were stratified for 15 days, the second sample were stratified for 3 days later (12 days), and the third sample were stratified after another 3 days ( 9 days), while some seeds are left without stratification. The seeds were sown after a given stratification period each in plastic pots $(25 \mathrm{~cm} \times 12 \mathrm{~cm})$ containing sterilized clean sand and kept under shade greenhouse conditions. Seedlings height $(\mathrm{cm})$, seedlings thickness $(\mathrm{mm})$, and fresh weight $(\mathrm{g})$ of the above ground portion as well as root fresh weight of seedlings were measured for each treatment 120 days after seed sowing.

\section{Determination of chemical constituents in seeds during CS}

In both seasons, samples of 15 seeds were taken at 3 days interval and extracted with the methanol being changed every $24 \mathrm{~h}$ [36]. The combined methanolic extracts were filtered and evaporated under vacuum at $40 \pm 2^{\circ} \mathrm{C}$ and transferred into aqueous phase for the following determinations:

\section{Determination of total, reducing, and non-reducing sugars}

Total and reducing sugars were determined as $\mathrm{mg} / \mathrm{g}$ dry weight using phosphomolybdic acid reagent [37]. Briefly, sample $(500 \mathrm{mg}$ ) of frozen seeds was crushed in a porcelain mortar and extracted with $50 \mathrm{ml}$ of $80 \%(\mathrm{v} / \mathrm{v}$ ) boiling ethanol for $5 \mathrm{~min}$. The sample was filtered to remove the insoluble material. The extract was centrifuged at $10,000 \mathrm{rmp}$ for 10 min. Then, the volume of the supernatant was adjusted to $100 \mathrm{ml}$ with water. Protein was precipitated by adding $1.0 \mathrm{~mL}$ of ethanol extract with $3 \mathrm{ml}$ of basic lead acetate $(137 \mathrm{~g} / \mathrm{L})$ and the excess lead acetate was precipitated with a solution of $1 \mathrm{M}$ sodium phosphate monobasic (141.7 $\mathrm{g} / \mathrm{L}$ ).The mixture was centrifuged and the volume of the supernatant was completed to $10 \mathrm{ml}$. For determining reducing sugars $1 \mathrm{ml}$ of the filtrate was mixed with $1 \mathrm{ml}$ of copper sulfate solution (13.2 g sodium sulfate and $6.0 \mathrm{~g}$ copper sulfate were dissolved in $1 \mathrm{~L}$ ) and $1 \mathrm{ml}$ of alkaline tartrate solution $(12 \mathrm{~g}$ sodium potassium tartrate, $20 \mathrm{~g}$ anhydrous sodium carbonate, $20 \mathrm{~g}$ sodium bicarbonate, and $18 \mathrm{~g}$ potassium oxalate were dissolved in $1 \mathrm{~L}$ ), then the mixture was heated in boiling water bath for 10 min. After cooling, $2 \mathrm{ml}$ of phosphomolybdic acid reagent $(23 \mathrm{~g}$ molybdic acid and $5 \mathrm{~g}$ sodium tungstate were dissolved in $200 \mathrm{ml}$ of $10 \%$ sodium hydroxide and boiled for 20-30 min. After cooling, $125 \mathrm{ml}$ of phosphoric acid were added and the volume was completed to $500 \mathrm{ml}$ with water) was added and the developed blue color was measured at $540 \mathrm{~nm}$. For determining total sugars, $1 \mathrm{ml}$ of the filtrate was mixed with $1 \mathrm{ml} 1 \mathrm{~N}$ HCL then the mixture was neutralized with sodium bicarbonate solution (1N), then the volume was completed to $5 \mathrm{ml}$. The total sugars were determined using a known volume $(1 \mathrm{ml})$, as described in the method of reducing sugars determination. For determining non-reducing sugars, the amount of reducing sugars was subtracted from the total sugars.

\section{Determination of total free amino acids}

Total free amino acids were determined as $\mathrm{mg} / \mathrm{g}$ dry weight according to Jayaraman [38] with some modifications [39]. A sample of leaves was extracted with $50 \mathrm{ml}$ of $80 \%$ ethanol and filtered to remove insoluble materials, and then $1.0 \mathrm{ml}$ of ethanol extract was added. Then, $0.5 \mathrm{ml}$ of $0.07 \mathrm{~mol} \mathrm{l-1}$ phosphate buffer solutions (pH 8.04) and $0.5 \mathrm{ml}$ of $2 \%$ ninhydrin solution containing $0.8 \mathrm{mg} / \mathrm{ml}$ of $\mathrm{SnC}_{12}-2 \mathrm{H}_{2} \mathrm{O}$ was added. The mixtures were then placed on a boiling water bath for $15 \mathrm{~min}$, and then quickly cooled with cold water, and adjusted to $25 \mathrm{ml}$ with water After leaving to stand still for $10 \mathrm{~min}$, the absorbance values of these blue-purple products were measured against a reagent blank at $550 \mathrm{~nm}$.

\section{Determination of total indoles}

Total indoles were extracted from leaves by grinding $2 \mathrm{~g}$ with $50 \mathrm{ml}$ toluene and $5 \mathrm{ml} \mathrm{5 \%}$ trichloroacetic acid for $1 \mathrm{~min}$. The mush was centrifuged at $\times 2500 \mathrm{~g}$ for $30 \mathrm{~min}$ to separate the toluene layer that was filtered through a $0.45 \mathrm{~m}$ syringe filter into a beaker containing anhydrous Na2SO4 (Aldrich). Total indoles were determined (as ug/g dry weight) according to Larson et al. [40]. The extract (4 ml) was diluted to $10 \mathrm{ml}$ with toluene, after which $2 \mathrm{ml}$ was vortexed for $15 \mathrm{~min}$ with $2 \mathrm{ml}$ reagent (1.25 g 4-dimethyl-aminobenzaldehyde in $100 \mathrm{ml} \mathrm{MeOH}$ and $25.6 \mathrm{ml}$ concentrated $\mathrm{HCl}$ ). The mixture was centrifuged at $3500 \mathrm{rpm}$ for $6 \mathrm{~min}$ to separate the $\mathrm{MeOH}$ (bottom) layer that was measured with spectrophotometer at $567 \mathrm{~nm} 2.9$.

\section{Determination of free, conjugated, and total phenols}

Free and total phenols in seeds were determined as mg/g dry weight using Folin-Ciocalteu reagent and sodium carbonate solution according to Galicia et al. [41] with some modification. Weigh a random sample of $(2 \mathrm{~g})$ seeds as a representative of the fresh material. Dry the seeds at $64-65^{\circ} \mathrm{C}$ for $16 \mathrm{~h}$. Grind each sample to a very fine powder.

\section{Extraction of free phenols}

Weigh $100 \mathrm{mg}$ of each powder of samples in an Eppendorf tube and add $6.5 \mathrm{ml}$ of methanol (50\%). Close the tubes and ensure no evaporation will take place during extraction. Vortex thoroughly the samples and place them in a thermo mixer at $65^{\circ} \mathrm{C}$ with $900 \mathrm{rpm}$ for $30 \mathrm{~min}$. Take the tubes out of the thermo mixer and let them to cooling at room temperature. Then, centrifuge the tubes at 14,000 rpm for $5 \mathrm{~min}$ and ensure the supernatant does not have sample particles floating in it; if it does, centrifuge again. Make the colorimetric reaction.

\section{Extraction of total phenols}

For each sample, weigh $100 \mathrm{mg}$ of powder in an Eppendorf and add $6.5 \mathrm{ml}$ of hydrochloric acid in methanol $(10 \mathrm{ml}$ of $\mathrm{HCl} 1.2 \mathrm{M}$ with $90 \mathrm{ml}$ methanol). Close the tubes and ensure no evaporation will take place during extraction. Vortex thoroughly the samples and place them in a ThermoMixer at $42^{\circ} \mathrm{C}$ and $1100 \mathrm{rpm}$ for $30 \mathrm{~min}$. Take the tubes out of the ThermoMixer and let them cool at room temperature. Centrifuge the tubes at 14,000 rpm for $5 \mathrm{~min}$. Ensure that the supernatant does not have sample particles floating in it; if it does, centrifuge again. Take $2.5 \mathrm{~mL}$ of supernatant, put it in new Eppendorf. Reduce to dryness and resuspend the precipitate resulting in $6.5 \mathrm{ml}$ of methanol. Vortex thoroughly and make the colorimetric reaction.

\section{Colorimetric reaction}

Take $1 \mathrm{~mL}$ of supernatant and carefully transfer into test tube. Then, add $0.8 \mathrm{~mL}$ of $5 \%$ Folin-Ciocalteu reagent (dissolve $10 \mathrm{~g}$ sodium tungstate and $2.5 \mathrm{~g}$ sodium molybdate in $70 \mathrm{ml}$ water). Add $5 \mathrm{ml} 85 \%$ phosphoric acid and $10 \mathrm{ml}$ concentrated hydrochloric acid. Reflux for $10 \mathrm{~h}$. Add $15 \mathrm{~g}$ lithium sulfate, $5 \mathrm{ml}$ water and 1 drop bromine. Reflux for $15 \mathrm{~min}$. Cool to room temperature and bring to $100 \mathrm{ml}$ with water. Then take $2.5 \mathrm{ml}$ of F-C $2 \mathrm{~N}$ with $7.5 \mathrm{ml}$ of deionized water and vortex thoroughly). The F-C reagent should be added before the alkali to avoid the air-oxidation of phenolics. Add 2.2 $\mathrm{mL}$ of $400 \mathrm{mM} \mathrm{Na}_{2} \mathrm{CO}_{3}$ (4.25 $\mathrm{g}$ of $\mathrm{Na}_{2} \mathrm{CO}_{3}$ [99.9\%] in $100 \mathrm{ml}$ of deionized water). Cover the tubes with adhesive aluminum tape to avoid dropping of samples. Vortex the tubes at $800 \mathrm{rpm}$ for $10 \mathrm{~s}$. Incubate tubes at $42^{\circ} \mathrm{C}$ for 9 $\mathrm{min}$ for color development. Take the tubes out of the oven and let them cool at room temperature, protect them from direct light. Read absorbance at $765 \mathrm{~nm}$ in a spectrophotometer. These estimates represented total phenols and free phenols. For determining conjugated phenols, the amount of free phenols was subtracted from the total phenols.

\section{Statistical analysis}

All studied treatments were arranged in a complete randomized block design with three replicates for each and were statistically analyzed according to the method of [42]. 


\section{RESULTS}

\section{Seed germination}

Data in Table 1 indicated that seed germination percentage in apricot "Local" variety was significantly increased (after 15 days germination at $25^{\circ} \mathrm{C}$ ) to $93 \%$ and $95 \%$ in 1998 and 1999 seasons, respectively, as compared to the control (non-stratified seeds).

The data also show that $\mathrm{CS}$ at $5^{\circ} \mathrm{C}$ had a stimulating effect on seed germination. Moreover, the number of days required for seed germination was decreased with the increase of CS period (Table 1).

\section{Vegetative growth of apricot seedling}

Vegetative growth of apricot seedling after 120 days from planting (Table 2) indicating that seedling developed from stratified seeds for 15 days had significantly the best vegetative growth compared with the corresponding ones developed from non-stratified seeds.

From the previous results, it can be concluded that apricot seeds "Local" variety required a CS period of about of 15 days to reach maximum germination and normal seedling growth.

Endogenous changes occurring in apricot seeds during CS

Total, reducing and non-reducing sugars, and total free amino acids concentration

Total, reducing and non-reducing sugars, and total free amino acids (Table 3) were present at lower levels in the initial extract of non- stratified seeds. A gradual increase was recorded with the advance of cold storage period to reach its maximum levels after 15 days CS in the first and second seasons.

Total, free and conjugated phenols, and total indoles concentration (mg/g D.W.) concentration

Total and conjugated phenols and total indoles concentration in apricot seeds (Table 4) were increased gradually with prolonging the cold storage period to reach its maximum values after 15 days stratification in 1998 and 1999 seasons, respectively. On the other hand, the free phenols concentration in apricot seeds (Table 4) were decreased gradually with prolonging the cold storage period to reach its minimum values after 15 days stratification in 1998 and 1999 seasons, respectively.

Conclusively, from the present results, it is clear that there was a relationship between seed germination and several changes in their chemical contents. Thus, some of these chemical increased such as total and reducing sugars, total free amino acids, total indoles, and total and conjugated phenols, while the other chemical decreased during seed germination as free phenols.

\section{DISCUSSION}

Apricot seeds are dormant and that dormancy breaking treatments have to be performed to obtain high germination and that the dormancy being caused by the permeability of the seed coat and fruit

Table 1: Effect of cold stratification period on germination\% of apricot seeds during 1998 and 1999 seasons

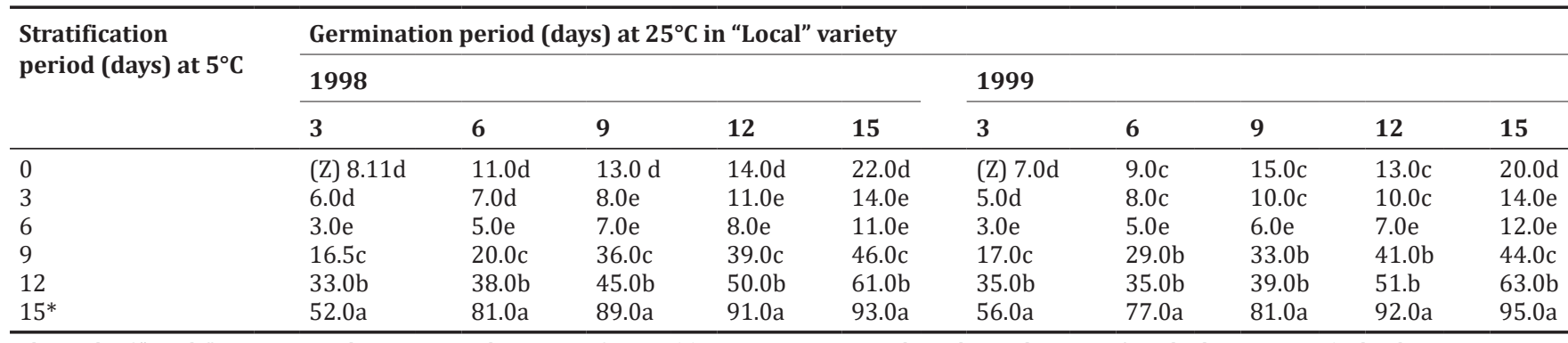

The seeds of "Localy" variety started to germinate during stratification (Z). Mean separation, within columns, by Duncan's multiple range test, $5 \%$ level

Table 2: Effect of cold stratification period on the items of seedling growth after 120 days from planting

\begin{tabular}{|c|c|c|c|c|c|c|c|c|}
\hline \multirow{2}{*}{$\begin{array}{l}\text { Stratification } \\
\text { period (days) } \\
\text { at } 5^{\circ} \mathrm{C}\end{array}$} & $\begin{array}{l}\text { Roots } \\
\text { weight (g) }\end{array}$ & $\begin{array}{l}\text { Shoot } \\
\text { weight (g) }\end{array}$ & $\begin{array}{l}\text { Seedling } \\
\text { height }(\mathrm{cm})\end{array}$ & $\begin{array}{l}\text { Seedling } \\
\text { thickness (mm) }\end{array}$ & $\begin{array}{l}\text { Roots } \\
\text { weight (g) }\end{array}$ & $\begin{array}{l}\text { Shoot } \\
\text { weight (g) }\end{array}$ & $\begin{array}{l}\text { Seedling } \\
\text { height }(\mathrm{cm})\end{array}$ & $\begin{array}{l}\text { Seedling } \\
\text { thickness (mm) }\end{array}$ \\
\hline & \multicolumn{4}{|l|}{1998} & \multicolumn{4}{|l|}{1999} \\
\hline 9 & $4.3 c$ & $6.5 b$ & $60.8 \mathrm{a}$ & $2.9 \mathrm{~b}$ & $4.4 \mathrm{~b}$ & $6.3 c$ & $58.6 \mathrm{~b}$ & $3.3 b$ \\
\hline 12 & $4.6 b$ & $9.0 \mathrm{a}$ & $61.0 \mathrm{a}$ & $4.2 \mathrm{a}$ & $4.7 a$ & $8.7 b$ & $62.3 \mathrm{a}$ & $4.0 \mathrm{a}$ \\
\hline 15 & $4.9 \mathrm{a}$ & 9.1a & $63.0 \mathrm{a}$ & $4.4 \mathrm{a}$ & $4.8 \mathrm{a}$ & $9.2 \mathrm{a}$ & $63.1 \mathrm{a}$ & $4.5 a$ \\
\hline
\end{tabular}

The values presented in the results obtained in this table is the mean of the two seasons under the study. Mean separation, within columns, by Duncan's multiple range test, $5 \%$ level

Table 3: Total, reducing and non-reducing sugars, and total free amino acids concentration (mg/g D.W.) in apricot seeds as affected by period of cold stratification during 1998 and 1999 seasons

\begin{tabular}{|c|c|c|c|c|c|c|c|c|}
\hline \multirow[t]{2}{*}{$\begin{array}{l}\text { Days of cold } \\
\text { stratification }\end{array}$} & \multicolumn{2}{|c|}{$\begin{array}{l}\text { Total sugars concentration } \\
\text { (mg/g D.W.) }\end{array}$} & \multicolumn{2}{|c|}{$\begin{array}{l}\text { Reducing sugars } \\
\text { concentration } \\
\text { (mg/g D.W.) }\end{array}$} & \multicolumn{2}{|c|}{$\begin{array}{l}\text { Non-reducing sugars } \\
\text { concentration } \\
\text { (mg/g D.W.) }\end{array}$} & \multicolumn{2}{|c|}{$\begin{array}{l}\text { Total free amino acids } \\
\text { concentration } \\
\text { (mg/g D.W.) }\end{array}$} \\
\hline & 1998 & 1999 & 1998 & 1999 & 1998 & 1999 & 1998 & 1999 \\
\hline 0 & 55.90 & 54.52 & 30.15 & 28.14 & 25.75 & 26.38 & 30.12 & 33.25 \\
\hline 3 & 60.21 & 63.18 & 33.58 & 35.17 & 26.63 & 22.08 & 61.25 & 64.28 \\
\hline 6 & 66.54 & 69.33 & 38.25 & 41.10 & 28.29 & 28.33 & 69.18 & 74.74 \\
\hline 9 & 89.28 & 85.39 & 51.28 & 55.50 & 38.0 & 89.29 & 78.20 & 81.58 \\
\hline 12 & 91.25 & 86.58 & 56.33 & 58.17 & 34.92 & 28.41 & 91.36 & 93.90 \\
\hline $15^{*}$ & 95.27 & 92.14 & 64.28 & 66.20 & 30.99 & 225.94 & 99.28 & 98.35 \\
\hline
\end{tabular}

Mean separation, within columns, by Duncan's multiple range test, $5 \%$ level 
Table 4: Total, free and conjugated phenols, and total indoles concentration (mg/g D.W.) in apricot seeds as affected by period of cold stratification during 1998 and 1999 seasons

\begin{tabular}{|c|c|c|c|c|c|c|c|c|}
\hline \multirow[t]{2}{*}{$\begin{array}{l}\text { Days of cold } \\
\text { stratification }\end{array}$} & \multicolumn{2}{|c|}{$\begin{array}{l}\text { Total phenols } \\
\text { concentration (mg/g D.W.) }\end{array}$} & \multicolumn{2}{|c|}{$\begin{array}{l}\text { Free phenols } \\
\text { concentration (mg/g D.W.) }\end{array}$} & \multicolumn{2}{|c|}{$\begin{array}{l}\text { Conjugated phenols } \\
\text { concentration (mg/g D.W.) }\end{array}$} & \multicolumn{2}{|c|}{$\begin{array}{l}\text { Total indoles } \\
\text { concentration (ug/g D.W.) }\end{array}$} \\
\hline & 1998 & 1999 & 1998 & 1999 & 1998 & 1999 & 1998 & 1999 \\
\hline 0 & 43.25 & 45.15 & 21.15 & 25.47 & 22.10 & 19.68 & 215.00 & 220.02 \\
\hline 3 & 51.00 & 49.58 & 18.33 & 20.10 & 32.67 & 29.48 & 255.10 & 268.36 \\
\hline 6 & 56.25 & 57.39 & 14.14 & 15.36 & 42.11 & 42.03 & 258.33 & 268.10 \\
\hline 9 & 57.90 & 60.30 & 10.15 & 12.33 & 47.75 & 47.97 & 298.11 & 321.00 \\
\hline $15^{*}$ & 69.32 & 71.58 & 8.58 & 8.00 & 60.74 & 63.58 & 341.11 & 357.10 \\
\hline
\end{tabular}

Mean separation, within columns, by Duncan's multiple range test, $5 \%$ level

pericarp rather than by the embryo [43,44]. Stratification, application usually increases the germination percentage of the seeds $[45,46]$. It is clear from the data that $\mathrm{CS}$ at $5^{\circ} \mathrm{C}$ had a stimulating effect on seed germination. In this respect, Lewak [47] reported that embryonic dormancy is defined as a set of blocks imposed upon a process(es) cardinal for growth. In apple seeds, all these blocks are removed as a result of cold treatment (stratification). Certain other block are responsible for dormancy of embryo, were removed as a result of a change in hormonal equilibrium [48]. Furthermore, Bogatek and Lewak [49] indicated that the elimination of embryonic dormancy in apple seeds was connected with a change from domination of pentose phosphate pathway to domination of glycolysis in sugar catabolism during CS. Furthermore, the percentage of seed germination depended not only on cultivar but also on the year of seed harvest [50]. The present study showed that stratification in water resulted in an increase of percentage of germinated seeds in comparison to control (untreated) seeds. The data also indicating that seedling developed from stratified seeds had significantly the best vegetative growth compared with the corresponding ones developed from non-stratified seeds. These results are in agreement with those of Kilany [51] who found that peach seedling height increased by increasing the period of CS of seed up to 60 days. The results also show that CS period increased total and reducing sugars, total free amino acids, and total indoles in seeds. In this respect, Jones and Armstrong [52] pointed out that the synthesis of a-amylase elicited by gibberellin usage and this leads to high levels of soluble carbohydrates and maltose as a starch hydrolysis in the endosperm. Moreover, Kilany [51] observed the accumulation of soluble amino acids in peach seed tissues as ripening progressed at CS. In addition, Daskalyuk et al. [53] found a decrease in the content of polypeptides in apple seeds with increasing period of stratification. On the other hand, Kopecky et al. [54] noted a certain auxin-like activity in partly cold-stratified apple seeds. The absence of free IAA in dormant seeds and in seeds submitted to cold treatment was finally confirmed 20 years later [55].

In contrast, the data also showed a decrease in the content of free phenols in apricot seeds with increasing period of stratification. In this concern, phloridzin (phloretin-b-D-glucoside) is the most abundant monomeric phenol in apple seeds. It amounts up to $8 \%$ of dry matter and in dormant seeds is located, together with condensed tannins, in the seed coat mainly [56]. Its level in the integument decreased to trace amounts during the first 20 days of stratification [57]. The huge concentration of phenolics in the coat has been postulated to play a role in maintaining the dormancy of the embryo [58]. On the other hand, lower concentrations of phloridzin, its aglycone phloretin, and other phenolics present in the embryo (e.g., chlorogenic acid) may play a secondary role in the control of dormancy, affecting the activity of important enzymes and thus at least some of the processes cardinal for the onset, maintenance, or removal of dormancy (e.g., [59]). Furthermore, Kefeli and Kutacek [60] suggested that plant phenol may be divided into three groups, promotive, inhibitor, and inactive. They added that promotion of plant growth by phenols may proceed through the modulation of either IAA biosynthesis or its destruction.

\section{REFERENCES}

1. Şan B, Yildirim AN, Yildirim F. An in vitro germination technique for some stone fruit species: The embryo isolated from cotyledons successfully germinated without cold pre-treatment of seeds. Am Soc Hortic Sci 2014;49:294-6.

2. Mousavi SR, Rezaei M, Mousavi A. A general overview on seed dormancy and methods of breaking it. Adv Environ Biol 2011;5:3333-7.

3. García-Gusano M, Martínez-Gómez P, Dicenta F. Breaking seed dormancy in almond (Prunus dulcis (Mill.) D.A. Webb). Sci Hortic 2004;99:363-70.

4. Shah RA, Sharma VK, Jasrotia WA, Plathia M. Effect of seed priming on peach, plum and apricot germination and subsequent seedling growth. Indian J Hortic 2013;70:591-4.

5. Baskin JM, Baskin CC. A classification system for seed dormancy. Seed Sci Res 2004;14:1-16.

6. Finch-Savage WE, Leubner-Metzger G. Seed dormancy and the control of germination. New Phytol 2006;171:501-23.

7. El-Yazal MA, Rady MM, El-Yazal SA. Metabolic changes in polyamines, phenylethylamine, and arginine during bud break in apple flower buds under foliar-applied dormancy-breaking. Int J Empir Educ Res 2018c;1:1-18.

8. El-Yazal MA. Seasonal changes in soluble and non-soluble carbohydrates during and after dormancy release in early and late varieties of apple (Malus Sylvestris, Mill) trees. Int J Empir Educ Res 2019b;3:1-18.

9. El-Yazal MA. Impact of chilling requirement on budburst, floral development and hormonal level in buds of early and late apple varieties (Malus sylvestris, Mill) under natural conditions. J Hortic Plant Res 2019c;8:1-11.

10. Sel-Yazal MA. Impact of chilling requirements on metabolic changes in nitrogenous compounds in buds during and after dormancy releasing in early and late (Malus sylvestris, Mill) apple varieties. Int Lett Nat Sci 2021;81:13-22.

11. El-Yazal MA, El-Yazal SA. Impact of chilling requirements on metabolic changes in nitrogenous compounds in buds during and after dormancy releasing in early and late (Malus sylvestris, Mill) apple varieties. Hortic Int J 2019a;3:230-8.

12. Han M, Zhang M, Tian Y, Zhang W, Zhang J. Effect of plant hormones on seed dormancy and seedling growth of stone fruits. Acta Bot Boreali Occident Sin 2002;22:1348-54.

13. Martinez-Gomez P, Dicenta F. Mechanisms of dormancy in seeds of peach [Prunus persica (L.) Batsch] cv. GF305 . Sci Hortic 2001;91:51-8.

14. Arbeloa A, Daorden M, Garci E, Andreu P, Marin JA. In vitro culture of 'Myrobalan' (Prunus cerasifera Ehrh.) embryos. Hortic Sci 2009;44:1672-4.

15. Rady MM, El-Yazal MA. Response of “Anna” apple dormant buds and carbohydrate metabolism during floral bud break to onion extract. Sci Hortic 2013; 155:78-84.

16. Rady MM, El-Yazal MA. Garlic extract as a novel strategy to hasten dormancy release in buds of "Anna" apple trees. S Afr J Bot 2014;92:105-11.

17. El-Yazal MA, Rady MM. Changes in nitrogen and polyamines during breaking bud dormancy in "Anna" apple trees with foliar application some compounds. Sci Hortic 2012a;136:75-80.

18. El-Yazal MA, Rady MM, Seif SA. Foliar-applied dormancy-breaking chemicals change the content of nitrogenous compounds in the buds of apple (Malus sylvestris Mill. cv. Anna) trees. J Hortic Sci Biotechnol 2012b;87:299-304. 
19. El-Yazal MA, Rady MM. Foliar-applied Dormex ${ }^{\mathrm{TM}}$ or thioureaenhanced proline and biogenic amine contents and hastened breaking bud dormancy in "Ain Shemer" apple trees. Trees 2013;27:161-9.

20. El-Yazal MA, Rady MM. Exogenous onion extract hastens bud break, positively alters enzyme activity, hormone, amino acids and phenol contents, and improves fruit quality in "Anna" apple trees. Sci Hortic 2014a;169:154-60.

21. El-Yazal MA, El-Yazal SA, Rady MM. Exogenous dormancy-breaking substances positively change endogenous phytohormones and amino acids during dormancy release in "Anna" apple trees. Plant Growth Regul 2014b;72:211-20

22. El-Yazal MA, Rady MM, El-Yazal SA. Foliar-applied mineral oil enhanced hormones and phenols content and hastened breaking bud dormancy in "Astrachan" apple trees. Int J Empir Educ Res 2018a;1:57-73.

23. El-Yazal MA, El-Yazal SA, Rady MM. Changes in promoter and inhibitor substances during dormancy release in apple buds under foliarapplied dormancy-breaking agents. Int J Empir Educ Res 2018b;1:1-20.

24. El-Yazal MA, Rady MM, El-Yazal SA, Morsi ME. Changes in metabolic processes during break dormancy in apple buds under foliarapplied garlic extract. Int J Empir Educ Res 2018d;1:36-58.

25. El-Yazal MA, El-Yazal SA, Morsi ME, Rady MM. Onion extract application effects on flowering behavior and yield, and a few chemical constituents of shoots throughout dormancy break in "Anna" apple trees. J Hortic Plant Res 2019b;7:1-15.

26. El-Yazal MA. Effect of timing of mineral oil spraying on budburst and metabolic changes in "Barkhar" apple trees under conditions of inadequate winter chilling in Egypt. Hortic Int J 2019a;3:67-75.

27. Mark R, Jo-Ann B, Paul W, Ercheng L, Masaji K. Maturity and temperature stratification affect the germination of Styrax japonicus seeds. J Hortic Sci Biotechnol 2015;79:645-51.

28. Keun SJ, Hee KJ, Kyung LA. Effect of warm and cold stratification, and ethanol treatment on germination of Corylopsis seeds. Hortic Sci 2016;43:84-91

29. Pliszko A, Kostrakiewicz-Gierałt K. Resolving the naturalization strategy of Solidago $\times$ niederederi (Asteraceae) by the production of sexual ramets and seedlings. Plant Ecol 2017a;218:1243-53.

30. Pliszko A, Kostrakiewicz-Gierałt K. Seed germination in Solidago $\times$ niederederi (Asteraceae) and its parental species after two different fruit storage periods. Biodivers Res Conserv 2017b;48:19-24.

31. Pliszko A, Kostrakiewicz-Gierałt K. Effect of cold stratification on seed germination in Solidago $\times$ niederederi (Asteraceae) and its parental species. Biologia 2018;73:945-50.

32. Górnik K, Grzesik M, Janas R, Żurawicz E, Chojnowska E, Góralska R. The effect of apple seed stratification with growth regulators on breaking the dormancy of seeds, the growth of seedlings and chlorophyll fluorescence. J Hortic Res 2018;26:37-44.

33. Seng M, Cheong EJ. Comparative study of various pretreatment on seed germination of Dalbergia cochinchinensis. For Sci Technol 2020;16:68-74.

34. Yan A, Chen Z. The control of seed dormancy and germination by temperature, light and nitrate. Bot Rev 2020;86:39-75.

35. Guo C, Shen Y, Shi F. Effect of temperature, light, and storage time on the seed germination of Pinus bungeana Zucc. ex Endl.: The role of seed-covering layers and abscisic acid changes. Forests 2020;11:300.

36. Diaz DH, Martin GC. Peach seeds dormancy in relation to endogenous inhibitors and applied growth substances. J Am Soc Hortic Sci 1972;97:651-4

37. AOAC. Official Methods of Analysis of the Association of Official
Agricultural Chemists. $16^{\text {th }}$ ed. Washington DC, USA: AOAC; 1995.

38. Jayaraman J. Laboratory Manual in Biochemistry. New York: Wiley Eastern Limited; 1981. p. 61-73.

39. Chen L, Chen Q, Zhang Z, Wana X. A novel colorimetric determination of free amino acids content in tea infusions with 2, 4-dinitrofluorobenzene. J Food Compost Anal 2009;22:137-41.

40. Larson P, Herlo A, Klunsour S, Asheim TA. On the biogenesis of some indole compounds in Acetobacter xylinum. Physiol Plant 1962;15:552-65.

41. Galicia L, Nurit E, Rosales A, Palacios-Rojas A. Laboratory Protocols: Maize Nutrition Quality and Plant Tissue Analysis Laboratory. Mexico CIMMYT; 2009.

42. Duncan DB. Multiple range and multiple F tests. Biometrics 1955;11:1-42

43. Eriş A. Bahçe Bitkileri Fizyolojisi. U Ü Z F Ders Notları 1990;11:152s

44. Murashige T, Skoog F. A revised medium for rapid growth and bioassays with tobacco tissue cultures. Physiol Plant 1962:15:473-97.

45. Serebryakova NV, Kalanova AI. The effect of water soluble vitamins on rose seed germination and rooting of cuttings. Hortic Abstr 1978;44:5819.

46. Tuzcu O, Kaplankıran M, Yesiloglu T, Ozcan M. The Effects of Germination and Developing of Different Preservation Methods on Pecan (Carya illinoensis) Seeds. Turkey First Nurseries Symposium. New Delhi: The Ministry of Agriculture Publication; 1991. p. 201-11.

47. Lewak S. Metabolic control of embryonic dormancy in apple seed Seven decades of research. Acta Physiol Plant 2011;33:1-24.

48. Lewak S. Regulatory pathways in removal of apple seed dormancy. Acta Hortic 1981;120:149-59.

49. Bogatek R, Lewak S. Effect of cyanide and cold treatment on sugar catabolism in apple seeds during dormancy removal. Physiol Plant 1988; 173:406-11.

50. Bewley JD, Black M. Seeds Physiology of Development and Germination. New York: Plenum Press; 1994. p. 445.

51. Kilany OA. Studies on germination of peach seeds. 1-Effect of seed coat, cold stratification and growth regulators. Ann Agric Sci 1986;24:2169-80.

52. Jones RL, Armstrong JE. Evidence for osmotic regulation of hydrolytic enzyme production in germinating barley seeds. Plant Physiol 1971;48:137-42.

53. Daskalyuk AP, Toma OK, Yarotskaya LV, Nikita II. Seed germination and polypeptide composition in early-and late-ripening apple cultivars as related to stratification time. Russ J Plant Physiol 1996;43:504-50.

54. Kopecky F, Sebanek J, Blazkova J. Time course of the changes in the level of endogenous growth regulators during the stratification of the seeds of the "Panenske ceske" apple. Biol Plant 1975;17:81-7.

55. Dziewanowska K, Lewak S. Non-decarboxylating transforma-tion of indol-3-acetic acid in apple seeds. Biol Plant 1987;29:110-7.

56. Dziewanowska K, Grochowska MJ, Lewak S. Changes inphloridzin and chlorogenic acid content and in indolylacetic acidoxidase activity during development of apple seeds. Fruit Sci Rep 1974;1:3-9.

57. Bogatek R, Podstolski A, Ostaszewska A, Lewak S. Phloridzin transformation and accumulation during the stratification of apple seeds and the culture of isolated embryos. Biol Plant 1976;18:241-50.

58. Come D. Relations entre l'oxygene et les phenomenes dedormance embryonnaire et d'inhibition tegumentaire. Bull Soc Frane Physiol Veg 1968;14:3145.

59. Dziewanowska K, Lewak S. Indolylacetic acid oxidase indormant apple embryos. Biol Plant 1975;17:207-13.

60. Kefeli V, Kutacek M. Phenolic substances and their possible role in plant growth regulation. Plant Growth Regul 1977;5:472. 